\title{
Model Pelaksanaan Pembelajaran Pada Masa Pandemi Covid 19 Sekolah Dasar Di Kabupaten Bima
}

\author{
A. Gafar Hidayat ${ }^{1)}$, Tati Haryati ${ }^{2), *}$ \\ ${ }^{1)}$ STKIP Taman Siswa Bima \\ *tatihistoris82@gmail.com
}

Informasi Artikel

Tanggal Publikasi

27 Desember 2021

Kata Kunci

Model BDR

Pembelajaran Masa Covid-19

\begin{abstract}
Abstrak
Tujuan penelitian; (1) Mendeskripsikan tentang Pelaksanaan BDR sekolah dasar; (2) Menyajikan dan menganalisis tentang hambatan pelaksanaan BDR sekolah dasar. Jenis penelitian ini, merupakan penelitian kualitatif dengan memanfaatkan informasi dari berbagai pihak yang berhubungan dengan pelaksanaan BDR dan disajikan dalam bentuk uraian dan simpulan. Sedangkan teknik pengumpulan datanya dilkukan dengan cara mewawancarai, semua pihak yang terlibat dalam pelaksanaan BDR, samapai pada orangtua/wali, hasil wawancara tersebut akan dibuat matriksnya sesuai indikator masalah kemudian akan dilakukan observasi untuk mengamati pelaksanaan BDR, agar mendapakan gambaran real tentang fenomena keberlangsungan BDR, dan yang terakhir akan dilakukan dokumentasi sebagai data pendukung dalam menelaah penelitian ini lebih lanjut. Sedangkan teknik analisis datanya dilskukan dengan cara menghimpun data hasil penelitian lapangan dalam bentuk pemetaan matriks data, setelah itu akan ditafsirkan dengan memberikan makna pada setiap informasi yang dikumpulkan sebelumnya, sehingga sampai pada langkah terakhir penarikan kesimpulan sebagai point yang di petakan dalam hasil penelitian. Berdasarkan hasil penelitian yang dilakukan yaitu; 1) Pelaksanaan BDR di sekolah dasar kurang efektif, ditinjau dari model pelasanaan, dan pendampingan orangtua belum maksimal; 2) Hambatan dalam pelaksanaan BDR di sekolah dasar yaitu kurangya fasilitas pendukung, motivasi dan minat siswa dalam belajar secara mandiri.
\end{abstract}

This is an open access article under the CC - BY license.

\section{PENDAHULUAN}

Model pelaksanaan BDR yang menjadi acuan semua instasi pendidikan bersarkan surat edaran Kementerian Pendidikan dan Kebudayaan Nomor 15 Tahun 2020 tentang Pedoman Penyelenggaraan Belajar Dari Rumah dalam Masa Darurat Penyebaran Covid-19 menyediakan alternatif kegiatan pembelajaran dengan meluncurkan program Belajar dari Rumah dan disediakan panduan untuk menjelaskan tujuan dan alternatif aktivitas bimbingan yang dapat dilakukan oleh orang tua dalam mendampingi anak saat menyaksikan dan mengerjakan program BDR, khususnya anak usia jenjang PAUD dan SD. Namun pada kenyataannya keterbatasan fasilitas dan sarana penunjang menjadi masalah utama, sehingga kurang efektifnya kegiatan pembelajaran online yang dianjurkan oleh sekolah.

Chuanmei Dong (2020) mengemukan bahwa siswa memiliki pengalaman belajar online selama pandemi, sekitar 84,6\% menghabiskan waktu kurang dari setengah jam setiap kali. Orang tua umumnya memiliki keyakinan negatif tentang nilai dan manfaat pembelajaran online dan lebih memilih pembelajaran normal, dengan tiga alasan utama; kekurangan waktu pembelajaran online, pengaturan waktu anak-anak yang tidak memadai, dan kurangnya waktu dan pengetahuan orangtua dalam mendukung pembelajaran online anak-anak. 
Sedangkan hasil publikasi jurnal Fieka Nurul Arifa bahwa Proses belajar dari rumah melalui pendidikan jarak jauh merupakan solusi yang dalam pelaksanaannya belum optimal secara keseluruhan. Terdapat berbagai hambatan, baik dari sisi sumber daya manusia, pengaturan penyelenggaraan, kurikulum, maupun sarana belajar. Komisi X DPR RI perlu mendorong sinergitas berbagai sektor terkait serta melakukan pengawasan agar pelaksanaan kebijakan belajar dari rumah dapat berjalan secara optimal (RI, B., Lt, G. N. I., \& Subroto, J. J. G.,2020). Hal ini menunjukkan bahwa penerapan pembelajaran online selama pandemi dapat dikatakan bermasalah dan kurang didukung oleh keluarga. Semua sekolah dasar yang ada di Kabupaten Bima, sudah berupaya menjalankan program BDR sesuai dengan surat edaran dari Kemendikbud untuk melaksanakan program KBM.

Penyelenggaraan belajar dari rumah pada masa darurat penyebaran Covid-19, dianggap perlu, dimana sekolah menjadi perhatian utama pemerintah, karena sekolah, menjadi tempat berkumpulnya guru dan siswa yang datang dari berbagai kalangan, sehingga menimbulkan kecemasan akan tertular virus covid 19. Kebijakan belajar di rumah dilaksanakan dengan tetap melibatkan pendidik dan peserta didik melalui Pembelajaran Jarak Jauh (Subroto, J. dkk., 2020).

Thom (2020) Sebelumnya belum pernah ada pembelajaran dengan sistem daring dilakukan secara serentak. Sedangkan di massa pandemi berlangsung, kini pembelajaran daring telah dilakukan di hampir seluruh dunia (Goldschmidt. K, 2020). Oleh karena itu pada belajar di rumah, menjadi bagian dari pendidikan tetap aktif meskipun tanpa tatap muka di kelas.

Pembelajaran saat ini sangat dianjurkan menggunakan media daring, dengan memanfaatkan kecanggihan teknologi. Menurut Rizqon Halal Syah Aji (2020) keterbatasan penguasaan teknologi informasi oleh Guru dan Siswa, membatasi mereka dalam menggunakan media daring. Sistem pembelajaran online di tingkat sekolah dasar, bisa mengubah wajah pendidikan menjadi lebih baik, lebih efektif, dan lebih menyenangkan. Guru menjadi lebih inovatif dalam mengemas bahan ajar dan lebih kreatif dalam mengembangkan metode pembelajaran untuk menarik antusiasme siswa. Namun, perlu disesuaikan lagi dengan berbagai kemampuan masing-masing guru, siswa, dan orang tua siswa dalam menyediakan fasilitas pembelajaran online ini, sehingga kendala yang dialami dapat diminimalisir (Lestari, P. A. S., \& Gunawan, G., 2020). Hal ini menjadi tantangan yang cukup besar bagi guru dan siswa, terutama karena penggunaan metode pembelajaran jarak jauh yang belum dibiasakan (Almanthari, A., Maulina, S., \& Bruce, S., 2020). Setiap elemen pendidikan dituntut untuk sesegera mungkin memaksimalkan penggunaan teknologi, dalam meningkatkan kreatifitas, dan inovasi pembelajaran jarak jauh (Zaharah, Z., Kirilova, G. I., \& Windarti, A.,2020).

Pendampingan orangtua sangat dibutuhkan oleh peserta didik dalam pelaksanaan BDR di massa Covid19, karena mereka lebih banyak waktu luang dibandingkan hari-hari normal sekolah, namun pada kenyataan kebanyakan orangtua terkendala dalam pendampingan belajar anak-anaknya lantaran sibuk dengan hal-hal lainya. Menurut Wardani, A., \& Ayriza, Y (2020) kendala-kendala orang tua dalam mendampingi anak belajar di rumah padamasa pandemi Covid-19 adalah kurangnya pemahaman materi oleh orang tua, kesulitan orang tua dalam menumbuhkan minat belajar anak, tidak memiliki cukup waktu untuk mendampingi anak karena harus bekerja, orang tua tidak sabar dalam mendampingi anak saat belajar di rumah, kesulitan orang tua dalam mengoperasikan gadget, dan kendala terkait jangkauan layanan internet. Program BDR dapat berdampak besar pada pelaksanaan KBM normal, karena dikhawatirkan pencapaian kurikulum menjadi terhambat dan sulitnya penilaian hasil belajar secara autentik. Oleh karena itu pihak terkait harus segera memikirkan langkah perbaikan untuk menanagani setiap kekuranga dalam pelaksanaan program BDR, ketika kondisi sudah kembali normal. Apabila diamati secara umum pelaksanaan BDR belum begitu efektif dan kurang didukung oleh orangtua atau wali yang memiliki memahaman awam terhadap program tersebut. Oleh karena itu pada penelitiaan ini peneliti ingin mencoba mendeskripsikan tentang sejauhmana pelaksanaan BDR yang dilakulan oleh sekolah dan keterlibatan guru-guru yang melakukan kunjungan dari rumah kerumah peserta didik. Kemudian melihat kurang maksimalnya pelaksanaan program tersebut, peneliti mencoba mendalami permasalahan yang menjadi kendala pelaksanan kegiatan tersebut dan mencoba menelaah dan mempelajari tanggapan orang tua peserta didik terhadap kegiatan beajar anak-anaknya di massa Pandemi covid19. Adapun Tujuan penelitian; (1) Mendeskripsikan tentang Pelaksanaan BDR sekolah dasar; (2) Menyajikan dan menganalisis tentang hambatan pelaksanaan BDR sekolah dasar. 


\section{METODE PENELITIAN}

Jenis penelitian ini, merupakan penelitian kualitatif dengan memanfaatkan informasi dari berbagai pihak yang berhubungan dengan pelaksanaan BDR dan disajikan dalam bentuk uraian dan simpulan, sehingga point kesimpulan dari penelitian ini berupa uraian tertulis, uraian yang diperoleh dari informan, dan perilaku subjek yang diamati. Penelitian ini juga, menunjuk pada prosedur penelitian yang menghasilkan data deskriptif, yaitu dilakukan secara fundamental berdasarkan informasi dari informan, baik lisan maupun tertulis.

\section{Teknik Pengupulan Data}

Peneliti menggunakan teknik wawancara terstruktur dan naratif untuk mendapatkaninformasi mengenai pelaksanaan BDR oleh sekolah dasar, dengan cara berdialog langsung dengan informan dengan mengajukan pertanyaan baik, yang telah disusun berdasarkan pedoman wawancara atau dilakukan secara naratif. Selanjutnya melakukan teknik observasi untuk mengamati fenomena keberlangsungan program BDR sekolah dasar. Kemudian yang terakhir melakukan teknik dokumentasi berupa catatan peristiwa yang sudah berlalu dapat berupa tulisan, gambar atau karya non monumental. Dokumen yang telah diperoleh kemudian dianalisis, sehingga membentuk suatu hasil kajian yang sistematis, padu dan utuh.

\section{Teknik Analisis Data}

Terlebih dahulu peneliti menghimpun atau mengumpulkan data di Sekolah Dasar, melalui wawancara, peneliti mencatat dan merekam semua jawaban-jawaban yang dikemukakan informan. Selanjutnya peneliti melakukan analisis dengan mereduksi data yakni merangkum semua hasil wawancara, observasi dan telaah dokumentasi kemudian memilih dan mengambil hal pokok, yang difokuskan pada permasalahan yang ingin dianalisis peneliti berdasarkan indikator. Selanjutnya peneliti menyajikan data yang dihimpun tersebut dalam bentuk narasi. Kemudian yang terakhir membuat kesimpulan awal yang ditemukan dapat bersifatsementara sehingga masih dapat berubah jika tidak didukung oleh bukti yang kuat. Jika bukti- bukti yang diperoleh telah kuat maka penelitian dianggap kredibel

\section{HASIL DAN PEMBAHASAN}

\section{Hasil Penelitian}

Menanggapi kondisi darurat bencana non-alam ini, Kementrian pendidikan Republik Indonesia mengeluarkan surat edaran Nomor 15 Tahun 2020 tentang pedoman penyelenggaraan belajar dari rumah pada masa darurat penyebaran covid-19 untuk semua sekolah di lingkup Kementerian tersebut. Kehawatiran akan penyebaran covid 19 di sekolah menjadi perhatian utama pemerintah, karena sekolah menjadi tempat berkumpulnya guru dan siswa yang datang dari berbagai kalangan, sehingga menimbulkan kecemasan akan tertular virus yang mematikan tersebut. Oleh karena itu pemerintah melalui kemendikbud menerapkan kebijakan belajar dari rumah. Kebijakan tersebut diberlakukan pada seluruh jenjang pendidikan mulai dari jenjang prasekolah hingga pendidikan tinggi, baik negeri maupun swasta. Kebijakan belajar di rumah dilaksanakan dengan tetap melibatkan pendidik dan peserta didik melalui Pembelajaran Jarak Jauh. Dengan tujuan; siswa mendapatkan layanan pendidikan selama darurat Covid-19, melindungi warga satuan pendidikan dari dampak buruk Covid-19. Mencegah penyebaran dan penularan Covid-19 di satuan pendidikan. Memastikan pemenuhan dukungan psikososial bagi pendidik, peserta didik dan orang tua/wali.

Seperti halnya sekolah-sekolah lain di lingkup Kemendikbud yang menerapakan belajar dari rumah (BDR). Pada awal-awal pelaksanaan program BDR ini, apabila dicermati dengan baik, secara umum pelaksanaannya belum begitu maksimal dan efektif, karena siswa mengganggap tidak ada aktifitas belajar secara mandiri di rumah melainkan sekolah diliburkan, karena kondisi darurat bencana Covid-19, serta kurangnya dukungan dari orangtua atau wali yang memiliki memahaman awam terhadap program tersebut, karena orangtua/wali juga menganggap anak-anaknya, tidak bersekolah sementara waktu akibat bencana Covid-19 ini. Fenomena ini yang terjadi pada awal-awal pelaksanaan program BDR oleh sekolah, sembari sekolah meninjau strategi yang tepat untuk pelaksanaan program belajar mandiri dirumah.

Berdasarkan keterangan narasumber yaitu kepala sekolah dan guru kelas kedua sekolah tersebut, pihak sekolah membuat perencanaan yang matang untuk mensiasati pelaksanaan BDR, dimana ada guru yang sanggup untuk mendatangi siswa dari rumah ke rumah, (door to door) demi kelengkapan materi pembelajaran siswa. 
Kemudian terdapat guru juga, yang mengumpulkan siswa-siswanya dalam jumlah kecil dan skala terbatas pada satu rumah siswa, untuk dikunjungi oleh gurunya dalam memberikan pembelajaran. Selanjunya terdapat guru juga yang berkoordinasi dengan orangtua siswa melalui washaap, untuk mengirim tugas dan materi pelajaran yang akan diberikan kepada siswa, namun hal ini kurang didukung sepenuhnya oleh orangtua, karena banyak yang terkendala dari segi ketersediaan akses internet dan kesiapan teknologi informasi masyarakat yang masih kurang.

Tabel 1. Model Pelaksanaan BDR di Sekolah dasar

\begin{tabular}{|c|c|c|}
\hline Rancangan Model & Penerapan & Analisis dan Simpulan \\
\hline Daring & $\begin{array}{l}\text { Tidak didukung oleh fasilitas, dan siswa dan orangtua terutama ketersediaan } \\
\text { akses jaringan internet. }\end{array}$ & Tidak efektif \\
\hline $\begin{array}{l}\text { Kunjungan guru dari rumah } \\
\text { kerumah siswa (door to door) }\end{array}$ & Berjalan selama $1-2$ pekan awal, diterapkan, dan guru merasa kewalahan. & Kurang efektif \\
\hline $\begin{array}{l}\text { Kunjungan guru ke tempat } \\
\text { perkumpulan siswa }\end{array}$ & $\begin{array}{l}\text { Berjalan selama } 1-2 \text { pekan awal pelaksanaan, dan kehawatiran tetap ada } \\
\text { kerumunan bagi siswa dan guru. }\end{array}$ & Kurang efektif \\
\hline Sip belajar di sekolah & $\begin{array}{l}\text { Berjalan tidak teratur, sewalaupun ada jadwal yang dibuat, karena siswa } \\
\text { datang ke sekolah tanpa seragam, dan hanya terbatas pada kelas tertentu. } \\
\text { Menunggu kesiapan guru dan siswa. }\end{array}$ & Kurang efektif \\
\hline Tatap muka terbatas & $\begin{array}{l}\text { Dilaksanakan sesuai jadwal sekolah, hanya saja jam belajar dikurangi dari } \\
\text { waktu normal dengan surat pernyataan persetujuan orangtua/wali (kesediaan } \\
\text { siswa masuk sekolah) }\end{array}$ & Efektif \\
\hline $\begin{array}{l}\text { Pendampingan belajar orangtua dan } \\
\text { guru }\end{array}$ & $\begin{array}{l}\text { Guru dan orangtua berkoordinasi melalui washaap japri/grub untuk akses } \\
\text { materi pelajaran dan tugas }\end{array}$ & Kurang efektif \\
\hline
\end{tabular}

\section{Pembahasan}

Model pembelajaran yang paling ideal diterapkan pada kondisi darurat bencana ini yaitu pembelajaran daring (dalam jaringan), dengan menggunakan platfom pembelajaran yang sudah tersedia, baik yang gratis maumun berbayar, akan tetapi hal ini tidak terlihat diterapkan di sekolah dasar, hal ini bukan terjadi karena kesengajaan dari pihak sekolah, namun terdapat beberapa kendala yaitu; fasilitas pendukung yang kurang memadai, dari pihak siswa. Dari hasil identifikasi siswa yang ada di kedua sekolah tersebut, hampir semua siswa tidak memiliki android/gedjet, jadi sulit untuk menerapkan pembelajaran dalam jaringan (daring).

Menurut Thome (2020) pembelajaran daring adalah pembelajaran yang menggunakan teknologi multimedia, kelas virtual, video, teks online animasi, email, pesan suara, telepon konferensi, dan video streaming online. Namun berbanding terbalik dengan kondisi kesiapan teknologi informasi guru dan masyarakat di kedua sekolah tersebut, hal ini menjadi pertimbangan pihak sekolah untuk merancang/mensiasati model BDR sefleksibel mungkin yang disesuaikan dengan kondisi siswa.

Selanjutnya kedua sekolah tersebut membuat rencana pelaksanaan BDR, mulai dari pembuatan jadwal dan sketjul untuk turun langsung ke rumah-rumah siswa, pembelajaran daring menggunakan platfom tertentu, strategi penyampaian materi dan tahapan penilaian hasil belajar selama pandemi covid 19, dengan melibatkan guru-guru kelas. Tahap awal sekolah menentukan topik kegiatan diantaranya; kunjungan dari rumah kerumah, tatap muka terbatas dengan kehadiran siswa di sekolah berdasarkan sift/pekan, beberapa siswa berkumpul di salah satu rumah untuk didatangi guru. Selain itu guru dan pihak sekolah membuka komunikasi dengan orangtua wali untuk memberikan penjelasan tugas orangtua dalam membantu anak-anaknya belajar mandiri di rumah. Namun hal ini kurang begitu efektif, apabila menyimak dari keterangan narasumber baik, dari guru maupun wali murid, karena kehawatiran terpapar Covid-19 untuk keluar rumah dan mengunjungi tempattempat tertentu. Sehingga tatap muka terbatas di sekolah tanpa ikatan waktu dan tempat menjadi alternatif dalam pelaksanaan BDR.

Pelaksanan BDR yang dilaksukan oleh kedua sekolah tersebut hampir sama, yaitu guru-guru yang ditugaskan oleh sekolah menerapkan model kunjungan dari rumah kerumah siswa, akan tetapi kegiatan ini hanya berlangsung satu atau dua pekan pertama dan dinilai terlalu banyak menyita tenaga guru yang terbatas. Sehingga guru-guru lebih memilih alternatif tatap muka terbatas di sekolah tanpa terikat waktu dan disesuikan dengan kondisi siswa maupun guru. Berdasarkan keterangan narasumber alokasi waktu tatap muka terbatas di sekolah dipersingkat dengan memperhatikan protokol kesehatan yang sangat ketat, sampai saat ini sistem pembelajaran tatap muka terbatas masih diberlakukan hanya saja perbedaannya siswa secara keseluruhan hadir di sekolah, dengan waktu pelajaran dipersingkat. 
Berdasarkan hasil identifikasi peneliti guru dan pihak sekolah dasar, pernah menerapkan pembelajaran daring dengan memanfaatkan platfom tertentu, yaitu WashApp orantua siswa, namun hal itu tidak begitu efektif karena hanya sebagian kecil saja yang mampu merespon dan memberikan umpan balik. Hal itu, terjadi karena terkendala di kesediaan akses internet (jaringan). Sehingga hal ini menjadi tidak efektif, ditambah lagi dengan tidak semua orangtua siswa punya dan tahu cara menggunakan gedjet/hp Android. Dari hasil keterangan salah satu narasumber dari wali siswa, tidak memiliki HP Android, dan kalupun dibeli tidak bisa digunakan, tentu dalam hal ini memerlukan waktu yang cukup lama untuk beradaptasi. Sehingga bisa dipastikan pembelajaran daring dengan platfom tertentu, tidak bisa digunakan, karena terkendala dengan akses jaringan.

Perencanaan pembelajaran yang dibuat oleh guru dari kedua sekolah tersebut, tidak begitu kaku dan sangat fleksibel dengan kondisi siswa saat ini, selalu memperhatikan minat dan bakat anak, untuk menyeimbangkan kondisi psikologis siswa selama pandemi Covid-19 berlangsung. Materi pelajaran yang disajikan lebih bersifat kontekstual, dengan segala keterbatasan ruang dan waktu, untuk itu guru memodifikasi materi pelajaran dengan membuat gambar sederhana, memberikan buku bacaan ringan bahkan dengan memberikan vidio yang sebelumnya dibuat. Tapi hal ini tetap tidak efektif apabila dilihat dari penghayatan siswa dan orang tua. Menurut Qozi \& Atikat (2021) pertimbangan mengadopsi pembelajaran jarak jauh berdarakan tingkat kesiapan teknologi dan kesadaran situasional. Kerena proses pembelajaran online memberikan siswa pengalaman belajar baru yang melibatkan interaksi tanpa batas di seluruh konten pembelajaran dan tanpa tatap muka secara langsung (Bernacki, M. L., Crompton, H., \& Greene, J. A., 2020). Namun hal ini tidak sejalan dengan kondisi yang ada, sehingga satu-satunya alternatif yaitu tatap tatap muka terbatas.

Model tatap muka terbatas paling ideal untuk menjaga keberlansungan penyampaian materi pelajaran siswa. Sewalaupun terbatas pihak sekolah tetap mengupayakan untuk dimaksimalkan, dengan cara memberikan tugas kepada siswa dan PR atau bahan bacaan untuk kelengkapan materi pelajaran. Seyogyanya proses belajar secara kontinu di rumah haru siswa lakukan dengan baik, namun tidak sesuai harapan. Kebanyakan siswa hanya belajar ketika ada tugas atau muncul hasrat ingin belajar. Ketika berada dirumah kecenderungan siswa lebih suka bermain dibandingkan belajar, akibatnya lupa dengan tugas belajar yang sudah guru berikan. Lupa akan tugas tersebut, membuat siswa terlambat dalam mengumpulkan tugas kepada gurunya. Proses belajar secara kontinyu sebenarnya baik untuk siswa lakukan di rumah, namun kenyataannya berbanding terbalik. Selama berada di sekolah dengan memanfaatkan waktu yang terbatas, siswa dibantu dan dipandu langsung oleh guru kelasnya, namun tidak didukung oleh pendampingan orangtua belajar secara mandiri di rumah, pada hal siswa lebih memiliki waktu yang cukup banyak di rumah untuk belajar di massa pandemi ini.

Apabila ditinjau dari pedoman pelaksanaan BDR yang dikeluarkan oleh Kemendikbud tugas pendidik meliputi; (1) Membuat mekanisme untuk berkomunikasi dengan orang tua/wali dan peserta didik; (2) Membuat RPP yang sesuai minat dan kondisi anak; (3) Menghubungi orang tua untuk mendiskusikan rencana pembelajaran yang inklusif sesuai kondisi anak didik; (4) Memastikan proses pembelajaran berjalan dengan lancar; (5) Bila tanpa tatap muka, guru mesti berkoordinasi dengan orangtua/wali untuk penugasan belajar; (6) Mengumpulkan dan merekap tugas yang dikirim peserta didik dalam waktu yang telah disepakati (Kemendikbud, 2020). Namun hal ini berbanding terbalik dengan proses pelaksanaannya dilapangan, kedua sekolah tersebut, sedemikian rupa telah mengupayakan dengan seluruh daya yang ada, sesuai dengan anjuran pedoman pelaksanaan BDR yang dikeluarkan oleh kemendikbud. Namun dengan mengingat kondisi yang kurang mendukung, jadi pelaksanaan BDR disiasati se-fleksibel mungkin dan lebih bersifat kondisional.

Permasalahan yang sering muncul dalam pelaksanaan BDR, yaitu tidak didukung oleh akses internet atau jaringan, dan kesiapan teknologi informasi masyarakat yang masih rendah. Hal ini juga terjadi di kedua sekolah tersebut. Seyogyanya jaringan internet dapat membuat pembelajaran jarak jauh atau dalam jaringan (daring) menjadi lebih efektif, tanpa terbatas oleh ruang dan waktu. Pihak sekolah sudah menyiapkan jaringan internet free, di lingkungan sekolah, sebagai sara penunjang dalam pelaksanaan pembelajaran daring, tapi hal itu belum bisa dimaksimalkan dengan baik. Permasalah yang menjadi hambatan BDR berbasis jaringan, juga datang dari siswa dan orangtuanya, karena tidak memiliki gedjet, leptop dan akses jaringan, sehingga penerapan model pembelajaran daring, tidak bisa dilakukan.

Selain itu yang menjadi penghambat bukan saja, permasalahan jaringan dan fasilitas penunjang lainnya, akan tetapi lebih besar kendalanya pada diri siswa itu sendiri, yang memaknai BDR adalah libur sekolah untuk sementara waktu, dan tidak disibukan dengan aktifitas belajar mandiri di rumah dan kecenderungan siswa 
menghabiskan waktunya untuk bermain. Berdasarkan hasil identifikasi yang dilakukan bahwa minat siswa belajar mandiri dirumah, sangat kurang bahkan tidak ada kemauan sama sekali. Kemudian orangtu siswa yang tidak memahami perannya sebagai pemandu anak-anaknya belajar mandiri dirumah. Pada hal, berdasarkan keterangan pihak sekolah, sudah menginformasikan kepada orangtua siswa, bahwa selama pandemi virus covid 19 ini, masuk kategori zona merah, aktivitas pembelajaran dipindahkan di rumah, dimana orangtua sebagai mentornya, termasuk sebagai perantara guru dengan siswanya tersebut. Selain itu kendala yang dihadapi oleh siswa, yaitu kurang dapat memahami, isi materi pelajaran yang diberikan oleh guru dalam bentuk print out atau protofolio, karena tidak adanya penjelas dari guru yang bersangkutan. Sehingga kehawatiran akan keberlangsungan materi pelajaran dapat terhambat dan juru berdampak pada hasil belajar yang diperoleh siswa. Seperti yang disampaikan oleh Seno \& Zainal (2019) kekurangan belajar jarak jauh yaitu materi pembelajaran menjadi kurang dimengerti saat pembelajaran tidak ditunjang dengan penjelasan dari guru secara langsung.

Pemahaman orangtua yang masih awam tentang program BDR menjadi salah satu hambatan dalam pelaksanaan program belajar dari rumah, sementara itu kemendikbud sudah menjelaskan peran orangtua dalam mendampingi anaknya belajar selama program intu diterapkan. Dimana peran orangtua meliputi; 1) Menyepakati cara untuk berkomunikasi dengan pihak sekolah;2) Mendiskusikan rencana pembelajaran yang inklusif bersama guru sesuai kondisi anak didik; 3) Menyiapkan perangkat pembelajarandan memastikan anak didik siap mengikuti pembelajaran; 4) Mendorong anak agar aktif selama proses pembelajaran (Kemendikbud, 2020). Namun pada kenyataannya banyak orangtua yang tidak memahami tugasnya dalam mendampingi anak belajar dirumah. Berdasarkan keterangan narasumber pembelajaran jarak jauh ini tidak cocok dengan kondisi di desa, tepatnya dilaksanakan dikota-kota besar saja. Sebab orangtua siswa, memiliki aktiftas ekonomi yang berfariasi dan tingkat kesejahteraan menengah kebawah, jadi sulit ada waktu untuk menjadi mentor atau memandu anak-anaknya untuk belajar secara mandiri di rumah. Berarti perbedaan persepsi guru dan orangtua tentang BDR, menjadi salah satu hambatan bagi efektifnya belajar dari rumah untuk siswa.

\section{KESIMPULAN}

Model Pelaksanaan BDR di Sekolah Dasar pada awalnya, kunjungan guru ke rumah siswa, dan tatap muka sift/rombel terbatas, namun kurang efektif, meskipun sekolah sudah mengikuti pedomannya dan model pelasanaan daring tidak digunakan mengingat kesiapan teknologi dan akses internet sangat terbatas. Adapun hambatan dalam pelaksanaan BDR di SDN Teke dan SD Inpres Teke yaitu kurangya fasilitas pendukung, kurangnya motivasi dan minat siswa dalam belajar secara mandiri, dan siswa kurang memahami materi yang diberikan oleh guru, tanpa penjelasan karena keterbatasan waktu, serta pebedaan persepsi antara sekolah dan orangtua dalam mendukung pelaksanaan BDR.

\section{Daftar Pustaka}

Aji, R. H. S. (2020). Dampak Covid-19 pada Pendidikan di Indonesia: Sekolah,Keterampilan, dan Proses Pembelajaran. Salam: Jurnal Sosial dan Budaya Syar-i.(7), 5, 395- 402

Almanthari, A., Maulina, S., \& Bruce, S. (2020). Secondary School Mathematics Teachers' Views on E-learning Implementation Barriers during the COVID-19 Pandemic: The Case of Indonesia. Eurasia Journal of Mathematics, Science and Technology Education, 16(7), em1860.

Bernacki, M. L., Crompton, H., \& Greene, J. A. (2020). Towards convergence of mobile and psychological theories of learning. Contemporary Educational Psychology, 60, 101828.

Betty Kusumaningrum dkk. (2020), "Pendampingan Orangtua dalam Pembelajaran Daring di Sekolah Dasar: Evaluasi Pembelajaran Daring Selama Masa Pandemi Covid-19,” Inventa: Jurnal Pendidikan Guru Sekolah Dasar Vol. 04 No 2

Dong, Chuanmei, Simin Cao, and Hui Li. (2020) "Young children's online learning during COVID- 19 pandemic: Chinese parents' beliefs and attitudes." Children and youth services review 118: 105440.

Goldschmidt, K. (2020). The COVID-19 Pandemic: Technology Use to Support the Wellbeing of Children. Journal of Pediatric Nursing

Kemendikbud (2020) Pedoman Pelaksanaan BDR Selama Darurat Bencana Covid-19. Jakarta: Kemendikbud pres 
Lestari, P. A. S., \& Gunawan, G. (2020). The Impact of Covid-19 Pandemic on Learning Implementation of Primary and Secondary School Levels. Indonesian Journal of Elementary and Childhood Education, 1(2), 58-63.

Lexy, J.Moleong (2018) Metode Penelitian kualitatif. Bandung: PT Remaja Rosdakarya.

Qazi A, Qazi J, Naseer K, et al (2021). Adaption of distance learning to continue the academic year amid COVID19 lockdown. Child Youth Serv Rev. 2021;126:106038. doi:https://doi.org/10.1016/j.childyouth.2021.106038

RI, B., Lt, G. N. I., \& Subroto, J. J. G. (2020). Tantangan pelaksanaan kebijakan belajar dari rumah dalam masa darurat Covid-1

Seno, \& Zainal, A. E. (2019). Persepsi Mahasiswa Terhadap Pelaksanaan E-Learning Dalam Mata Kuliah Manajemen Sistem Informasi. Jurnal Kajian Teknologi Pendidikan, 02,

Sun, L., Tang, Y., \& Zuo, W.(2020). Coronavirus Pushes Education Online. Nature Materials, 19(6), 687-687.

Tirajoh, Wailan Thom (2020). One-Shot Learning Face Recognition untuk Presensi Akademik menggunakan Deep Convolutional Neural Network. S1 thesis, Universitas Atma Jaya Yogyakarta

Wardani, A., \& Ayriza, Y. (2020). Analisis Kendala Orang Tua dalam Mendampingi AnakBelajar di Rumah Pada Masa Pandemi Covid-19. Jurnal Obsesi: Jurnal Pendidikan Anak Usia Dini, 5(1), 772-782 